\title{
KAJIAN LITERATUR TENTANG REDUKSI KROMIUM DALAM AIR LIMBAH PENYAMAKAN KULIT DENGAN FITOREMEDIASI
}

\author{
Dwi Astuti, Nurul Sukmawati, Rezania Asyfiradayati, Sri Darnoto \\ Universitas Muhammadiyah Surakarta, Indonesia \\ Email: da168@ums.ac.id,n.sukmawati215@gmail.com,ra123@ums.ac.id, \\ sd194@ums.ac.id
}

\begin{abstract}
Abstrak
Industri penyamakan kulit merupakan penyumbang polutan krom $(\mathrm{Cr})$ pada limbahnya. Fitoremediasi memanfaatkan tanaman eceng gondok pada penurunan krom dalam limbah industri. Tujuan penelitian ini yaitu untuk mengetahui penerapan fitorremediasi dalam menurunkan kandungan krom pada limbah industri penyamakan kulit. Metode penelitian menggunakan desain penelitian kajian literatur yang menggunakan database Google Scholar, SINTA, Science Direct. Penelusuran literatur dimulai pada tahun terbit 2011 sampai tahun 2021 untuk dilakukan analisis. Kata kunci yang digunakan dalam penelusuran artikel menggunakan bahasa Indonesia dan bahasa Inggris yaitu penurunan $\mathrm{Cr}$, air limbah industri penyamakan kulit, efisiensi eceng gondok, fitoremediasi pada industri penyamakan kulit. Kriteria inklusi tujuan penelitian dalam artikel yaitu penurunan logam berat kromium pada limbah industri penyamakan kulit menggunakan fitoremediasi, dapat diakses secara full text, metode kuantitatif eksperimen, jurnal yang diterbitkan ber-ISSN dan SINTA $1-6$. Berdasarkan penelusuran diperoleh semua jurnal berhasil menurunkan kromium dalam air limbah dalam durasi lama waktu kontak 7 hari, 14, hari, 21 hari, 10 hari, 20 hari, 25 hari, 15 hari, 42 hari. Hasil penurunan dikatakan efektif jika berhasil menurunkan kandungan $\mathrm{Cr}$ hingga sesuai standar baku mutu yaitu pada lama waktu kontak 10 hari, 20 hari dan 28 hari. Metode fitoremediasi memiliki beragam kemudahan karena memanfaatkan tumbuhan air yang mudah diberdayakan. Oleh karena itu, pemanfaatan metode fitoremediasi ini diperlukan pengawasan terhadap pertumbuhan tanaman eceng gondok agar dapat bekerja optimal menurunkan kandungan logam krom dalam air limbah.
\end{abstract}

Kata Kunci: fitoremediasi; penurunan krom; industri penyamakan kulit

\section{Abstract}

The leather tanning industry is a contributor to the pollutant chromium $(\mathrm{Cr})$ in its waste. Phytoremediation utilizes water hyacinth plants to reduce chromium in industrial effluents. This study purposed to know the application the effectiveness of phytoremediation in reducing chromium content in leather tanning industrial waste. The research method uses a literature review research design that uses the Google Scholar database, SINTA, Science Direct. The literature search began in 2011 until 2021 for analysis. The keywords used in the search for articles using

$\begin{array}{ll}\text { How to cite: } & \text { Astuti. D., Nurul Sukmawati, Rezania Asyfiradayati \& Sri Darnoto (2022) Kajian Literatur Tentang Reduksi } \\ & \text { Kromium dalam Air Limbah Penyamakan Kulit dengan Fitoremediasi. Syntax Literate: Jurnal Ilmiah Indonesia, } \\ & 7(1) . \text { http://dx.doi.org/10.36418/ Syntax-Literate.v7i1.5723 } \\ \text { E-ISSN: } & 2548-1398 \\ \text { Published by: } & \text { Ridwan Institute }\end{array}$


Indonesian and English are $\mathrm{Cr}$ reduction, tannery industry wastewater, water hyacinth efficiency, phytoremediation in the leather tanning industry. The inclusion criteria for the research objective in the article are the reduction of heavy metal chromium in leather tanning industry waste using phytoremediation, accessible in full text, experimental quantitative methods, journals published with ISSN and SINTA 1 - 6. wastewater in long duration of contact time 7 days, 14 days, 21 days, 10 days, 20 days, 25 days, 15 days, 42 days. The results of the reduction were said to be effective if they succeeded in reducing the Cr content to meet the quality standards, namely the contact time of 10 days, 20 days and 28 days. The phytoremediation method has various conveniences because it utilizes aquatic plants that are easily empowered. Therefore, the use of this phytoremediation method requires monitoring the growth of water hyacinth plants in order to work optimally to reduce the chromium metal content in wastewater.

Keywords: phytoremediation; chromium reduction; leather tanning industry

Received: 2021-12-20; Accepted: 2022-01-05; Published: 2022-01-15

\section{Pendahuluan}

Perkembangan industri memberikan dampak pada segala aspek kehidupan manusia termasuk kontrol lingkungan. Aktivitas industri menjadi sumber pencemaran lingkungan saat ini yang mengakibatkan masuknya bahan-bahan kimia dalam limbah yang dapat mengontaminasi sumber air di sekitarnya. Kondisi ini menyebabkan penurunan kualitas air sehingga tidak layak untuk digunakan (Ugya \& Aziz, 2016). Limbah hasil kegiatan industri merupakan penyumbang limbah terbanyak pertama di dunia. Setiap tahun di India sekitar 50.000 juta liter air dari limbah industri maupun limbah domestik dihasilkan dari daerah perkotaan. Sementara itu, infrastruktur pengolahan air limbah di India hanya mampu mengolah sekitar 2,8\% limbah cair domestik dan $60 \%$ limbah cair industri, sehingga banyak limbah cair yang tidak diolah namun dibuang langsung menuju sungai (Chakraborty \& Mukhopadhyay, 2012).

Negara India merupakan produsen kulit terbesar ketiga di dunia yang memiliki sekitar 3000 industri penyamakan dengan kapasitas pengolahan tahunan sebesar 0,7 juta ton kulit. Wilayah Uttar Pradesh, Jajmau, India merupakan kota industri paling banyak dengan sekitar 400 industri penyamakan kulit terletak di tepi sungai Gangga yang mengkhususkan diri pengolahan kulit menjadi kulit berat (Bhaskar Gupta \& Huang, 2014). Sementara itu, produksi tahunan bahan mentah (kulit) yang diproses di industri penyamakan kulit Bangladesh sekitar 85.000 ton. Industri penyamakan kulit menjadi salah satu industri dengan produksi limbah cair yang besar. Pada penyamakan 1 ton kulit basah diperlukan air $\pm 40 \mathrm{~m}^{3}$ dan kemudian akan dibuang ke badan air yang tercampur dengan sisa bahan kimia dan komponen lainnya yang terlarut (Paul, et al, 2013).

Limbah penyamakan kulit digolongkan sebagai polutan tertinggi di antara semua limbah industri. Limbah yang dihasilkan dari industri ini memliki kandungan yang kompleks dan menyebabkan pencemaran. Polutan dari sejumlah besar penyamakan kulit 
di dunia memiliki penyebab kerusakan aliran air, mempengaruhi pasokan air minum dan irigasi (Ugya \& Aziz, 2016). Senyawa anorganik utama dalam limbah industri berupa logam berat. Logam berat tidak dapat didegradasi secara biologis, tetapi hanya dapat dialihrupakan atau dipindahtempatkan. Keberadaan logam berat dalam air akan diserap dan diakumulasi dalam sel organisme yang hidup dalam lingkungan tersebut (Safarrida \& Ngadiman, 2015).

Proses penyamakan kulit merupakan proses penyamakan terhadap kulit dengan menggunakan berbagai bahan kimia sebagai pembantu proses tersebut. Krom $(\mathrm{Cr})$ merupakan bahan penyamak kulit yang paling banyak digunakan pada industri penyamakan kulit dan sekitar $85 \%$ kulit dunia disamak menggunakan krom. Penggunaan $\mathrm{Cr}$ pada penyamakan kulitmemberikan keungulan salah satunya kemudahan saat proses retanning (Safarrida \& Ngadiman, 2015). Senyawa kromium (Cr) dalam limbah cair industri penyamakan kulit berasal dari proses produksi penyamakan kulit, dimana pada proses penyamakan kulit hanya sebagian kecil kromium (Cr) yang digunakan dalam proses penyamakan dan sisanya dibuang sebagai produk sampingan dari pengolahan air limbah.

Keberadaan logam $\mathrm{Cr}$ di perairan menyebabkan penurunan kualitas air serta membahayakan lingkungan dan organisme akuatik. Kromium dalam jangka panjang dapat menyebabkan terjadinya suatu gangguan kesehatan seperti, alergik hingga tumbuhnya kanker paru-paru, kerusakan hati (liver) dan ginjal. Jika terjadi kontak dengan kulit dapat menyebabkan iritasi dan jika tertelan dapat menyebabkan sakit perut dan muntah (Direktorat Pengawasan Produk dan Bahan Berbahaya, 2010). Akumulasi unsur logam berat dapat mengakibatkan terjadinya interaksi antara logam berat dengan sel atau jaringan tubuh. Kromium heksavalen merupakan logam kromium yang bersifat karsinogenik dan korosif pada jaringan tubuh dibandingkan ion kromium lainnya seperti, $\mathrm{Cr}^{2+}$ dan $\mathrm{Cr}^{3+}$. Sifat toksik kromium tersebut dapat menyebabkan keracunan akut dan keracunan kronis (Adhani, 2017).

Industri penyamakan kulit penyumbang polutan $\mathrm{Cr}$ dalam air limbahnya, jika tidak diolah dapat mencemari badan air. Keberadaan polutan ini dapat menyebar pada komponen abiotik lainnya seperti tanah, air tanah dan lingkungan biotik seperti tumbuhan dan hewan. Terdapat beberapa metode yang dapat menghasilkan penurunan 90\% kandungan polutan krom dalam air limbah penyamakan kulit, namun teknologi tersebut mahal, boros energi dan butu tenaga terampil untuk operasional. Metode lain yang dapat digunakan dengan lebih ekonomis, sederhana, dan efektif untuk menurunkan kandungan krom dalam air limbah penyamakan kulit salah satunya dengan menggunakan (Nurlaili, Rahayu, \& Dewi, 2020). Fitoremediasi merupakan suatu teknologi inovatif pengolahan limbah, yang dapat menjadi teknologi alternatif dalam menangani pencemaran karena menggunakan tumbuhan air sebagai fitoremediator yang dapat mengubah zat kontaminan (pencemar/polutan) menjadi kurang atau tidak berbahaya dan bahkan menjadi bahan yang berguna secara ekonomi (Irhamni et al., 2018). Menurut (Muthoharoh, 2018) semua tumbuhan mampu menyerap logam dalam jumlah yang bervariasi tetapi beberapa tumbuhan mampu mengakumulasi unsur logam 
tertentu dalam konsentrasi yang cukup tinggi. Beberapa jenis tumbuhan air yang dapat dijadikan tumbuhan akumulator dalam menyerap logam berat krom (Cr) salah stunya yaitu tumbuhan Eichhornia crassipes (Irhamni et al., 2018).

Berdasarkan hasil penelitian dari (Hartanti et al., 2014) pada industri penyamakan kulit menunjukkan konsentrasi chromium dalam limbah cair penyamakan kulit tergolong cukup tinggi, yaitu $2.71 \mathrm{mg} / \mathrm{l}$. Setelah dilakukan fitoremediasi diperoleh hasil kerapatan tumbuhan eceng gondok (Eichhornia Crassipes) dalam proses fitoremediasi dapat menurunkan logam $\mathrm{Cr}$ pada hari ke-28 menjadi sebesar $2.23 \mathrm{mg} / \mathrm{l}$. Penelitian lain yang dilakukan oleh (Woldemichael, Zewge, \& Leta, 2011) menyebutkan tumbuhan eceng gondok memiliki efisiensi penurunan logam $\mathrm{Cr}$ sebesar $91 \%$ pada air limbah penyamakan kulit.

Berdasarkan uraian tersebut diketahui bahwa kandungan logam $\mathrm{Cr}$ pada limbah industri penyamakan kulit dapat menyebabkan pencemaran lingkungan sehingga perlu dilakukan pendekatan lebih lanjut tentang potensi tumbuhan air untuk proses penurunan logam Cr. Oleh karena itu, peneliti ingin melakukan studi literatur terkait penerapan fitoremediasi menggunakan tumbuhan air untuk menurunkan logam $\mathrm{Cr}$ dalam limbah industri penyamakan kulit.

\section{Metode Penelitian}

Metode penelitian ini adalah kajian literatur, yaitu metode penelitian dengan cara mengulas khusus atau merangkum pustaka empiris atau teoritis untuk memberikan pemahaman yang lebih komprehensif tentang penerapan fitoremediasi dalam menurunkan logam berat kromium $(\mathrm{Cr})$ pada limbah cair industri penyamakan kulit. Penelusuran artikel terkomputerisasi menggunakan database Google Scholar, SINTA, Science Direct. Penelusuran literatur dimulai pada tahun terbit 2011 sampai tahun 2021 untuk dilakukan analisis. Kata kunci yang digunakan dalam penelusuran artikel menggunakan bahasa Indonesia dan bahasa Inggris yaitu penurunan $\mathrm{Cr}$, air limbah industri penyamakan kulit, efisiensi eceng gondok, fitoremediasi pada industri penyamakan kulit. Adapun kriteria inklusi dan eksklusi sebagai berikut:

a. Kriteria Inklusi

1) Tujuan penelitian dalam artikel yaitu penurunan logam berat kromium pada limbah industri penyamakan kulit menggunakan metode fitoremediasi tanaman eceng gondok

2) Artikel dapat diakses secara full text

3) Metode yang digunakan dalam jurnal adalah kuantitatif eksperimen

4) Jurnal yang diterbitkan ber-ISSN (International Standart Serial Number) dan SINTA $1-6$

b. Kriteria Eksklusi

Kriteria eksklusi dalam penelitian ini adalah artikel telah dipublikasikan sebelum tahun 2011 dan artikel yang tidak bisa diakses secara lengkap. Diagram alur seleksi yang digunakan dalam pencarian jurnal pada penelitian ini adalah sebagai berikut: 
Dwi Astuti, Nurul Sukmawati, Rezania Asyfiradayati, Sri Darnoto

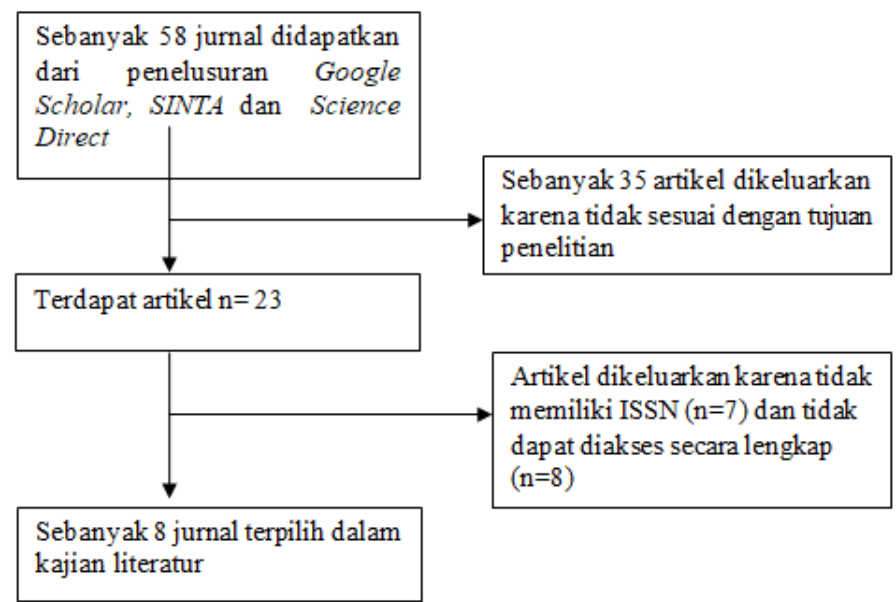

Gambar 1

Alur Seleksi Jurnal

\section{Hasil Dan Pembahasan}

\section{A. Hasil Penelitian}

Berikut ini merupakan hasil penyaringan jurnal yang akan dianalisis menggunakan kajian literatur diperoleh sebanyak 8 jurnal. Gambaran hasil analisis jurnal tersebut akan ditampilkan dalam bentuk tabel berikut ini: 
Tabel 1

Hasil Analisis Metode Penelitian

\begin{tabular}{|c|c|c|c|c|c|}
\hline Peneliti, Tahun, Judul & Jurnal & Sampel & Variabel Bebas & Variabel Terikat & Uii Statistik \\
\hline $\begin{array}{lrr}\text { (Hartanti, Haji, \& Wirosoedarmo, } \\
\text { 2014) Pengaruh } & \text { Kerapatan } \\
\text { Tanaman } \quad \text { Eceng } & \text { Gondok } \\
\text { (Eichhornia cassipes) } & \text { Terrhadap } \\
\text { Pertumbuhan Logam } & \text { Chromium } \\
\text { Pada Limbah Cair Penyamakan } \\
\text { Kulit }\end{array}$ & $\begin{array}{l}\text { Jurnal Sumberdaya Alam dan } \\
\text { Lingkungan } \\
\text { https://jsal.ub.ac.id/index.php/jsal/artic } \\
\text { le/view/124\#: :text=Data\%20hasil\%2 } \\
\text { 0penelitian\%20menunjukkan\%20bahw } \\
\text { a,sebesar\%202.20\%20mg\%20L\%2D1 } \\
\text { \%2C }\end{array}$ & $\begin{array}{l}\text { Air limbah } \\
\text { industri } \\
\text { penyamakan } \\
\text { kulit Kec. } \\
\text { Sukun Kota } \\
\text { Malang }\end{array}$ & $\begin{array}{l}\text { Kerapatan tanaman } \\
(2,4,6 \text { tanaman) dan } \\
\text { lama waktu }(0,7,14, \\
21,28 \text { hari) }\end{array}$ & $\begin{array}{l}\text { Penurunan logam } \\
\text { krom }\end{array}$ & $\begin{array}{l}\text { ANOVA dan } \\
\text { Uji Beda } \\
\text { Nyata } \\
\text { Terkecil } \\
\text { (BNT) }\end{array}$ \\
\hline $\begin{array}{l}\text { (Putri, Holik, Musfiroh, \& Aryanti, } \\
\text { 2014) Pemanfaatan Tanaman } \\
\text { Eceng-Ecengan (Ponterideceae) } \\
\text { Sebagai Agen Fitoremediasi dalam } \\
\text { Pengolahan Limbah Krom }\end{array}$ & $\begin{array}{l}\text { Indonesian Journal Of Pharmaceutical } \\
\text { Science and Technology } \\
\text { http://jurnal.unpad.ac.id/ijpst/article/vi } \\
\text { ew/7510/3443 }\end{array}$ & $\begin{array}{l}\text { Air limbah } \\
\text { industri } \\
\text { penyamakan } \\
\text { kulit Desa } \\
\text { Sukaregang, } \\
\text { Garut }\end{array}$ & $\begin{array}{l}\text { Lama waktu }(7,14, \\
21 \text { hari) }\end{array}$ & Penurunan krom & $\begin{array}{l}\text { ANAVA } \\
\text { Rancangan } \\
\text { Acak } \\
\text { Lengkap } \\
\text { (RAL) }\end{array}$ \\
\hline $\begin{array}{l}\text { (Chakrabarty, Afrin, Mia, \& } \\
\text { Hossen, 2017) Phytoremediation of } \\
\text { Chromium and Some Chemical } \\
\text { Parameters from Tannery Effluent } \\
\text { by Using Water Hyacinth } \\
\text { (Eichhornia crassipes) }\end{array}$ & $\begin{array}{l}\text { Research in Agriculture, Livestock and } \\
\text { Fisheries (RALF) } \\
\text { https://www.banglajol.info/index.php/ } \\
\text { RALF/article/view/35091 }\end{array}$ & $\begin{array}{l}\text { Air limbah } \\
\text { industri } \\
\text { penyamakan } \\
\text { kulit di } \\
\text { Hazaribagh } \\
\text { Thana } \\
\text { Bangladesh }\end{array}$ & $\begin{array}{l}\text { Lama waktu }(7 \& 15 \\
\text { hari) }\end{array}$ & $\begin{array}{l}\text { Penurunan pada } \\
\text { parameter kimia (pH, } \\
\text { TDS, EC, BOD, Cr) }\end{array}$ & $\begin{array}{l}\text { Tidak } \\
\text { dijelaskan }\end{array}$ \\
\hline $\begin{array}{l}\text { (Agarwal, Singh, \& Rai, 2013) } \\
\text { Bioremediation of Tannery Effluent } \\
\text { by Using Pseudomonas flourescens } \\
\text { and Eichornia crassipes and Its } \\
\text { Effect on Wheat Seed Germination } \\
\text { and Plant Growth }\end{array}$ & $\begin{array}{l}\text { G-Journals Of Environt-mental } \\
\text { Science and Technology } \\
\text { https://gjestenv.com/index.php/gjest/ar } \\
\text { ticle/view/4 }\end{array}$ & $\begin{array}{l}\text { Air limbah } \\
\text { industri di } \\
\text { Distik Unnao, } \\
\text { Uttar Pradesh }\end{array}$ & $\begin{array}{l}\text { Lama waktu }(10 \& \\
20 \text { hari })\end{array}$ & $\begin{array}{l}\text { Parameter air limbah } \\
\text { (pH, TDS, EC, Cr, } \\
\text { COD, TSS, BOD) }\end{array}$ & $\begin{array}{l}\text { Tidak } \\
\text { dijelaskan }\end{array}$ \\
\hline 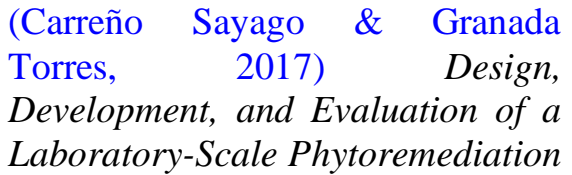 & $\begin{array}{l}\text { Tecciencia } \text { Vol 12,No } 22 \\
\text { http://www.scielo.org.co/scielo.php?sc } \\
\text { ript=sci_arttext\&pid=S1909- } \\
36672017000100007\end{array}$ & $\begin{array}{l}\text { Air limbah } \\
\text { industri } \\
\text { penyamakan } \\
\text { kulit } \quad \text { St. }\end{array}$ & $\begin{array}{l}\text { Lama waktu } \\
\text { (pengukuran } \\
\text { dilakukan setiap } 2 \\
\text { hari sekali) }\end{array}$ & $\begin{array}{l}\text { Tingkat penurunan } \\
\text { kromium heksavalen } \\
(\mathrm{Cr} \text { VI) }\end{array}$ & $\begin{array}{l}\text { Tidak } \\
\text { dijelaskan }\end{array}$ \\
\hline
\end{tabular}




\begin{tabular}{|c|c|c|c|c|c|}
\hline $\begin{array}{l}\text { System Using Eichhornia Crassipes } \\
\text { for the Treatment of Chromium- } \\
\text { Contaminated Waters }\end{array}$ & & $\begin{array}{l}\text { Benedict } \\
\text { Colombia }\end{array}$ & & & \\
\hline $\begin{array}{l}\text { (Kiran Gupta, 2014) Modulation } \\
\text { Antioxidant Defence Systemfor } \\
\text { Detoxification of Oxidative Stress } \\
\text { Caused by Tannery Eflluent }\end{array}$ & $\begin{array}{l}\text { International Jourrnal of Environtment } \\
\text { https://www.researchgate.net/publicati } \\
\text { on/270127205_Modulation_of_antioxi } \\
\text { dant_defence_system_for_detoxificati } \\
\text { on_of_oxidative_stress_caused_by_tan } \\
\text { nery_effluent_in_Eichhornia_crassipes }\end{array}$ & $\begin{array}{l}\text { Air limbah } \\
\text { industri } \\
\text { penyamakan } \\
\text { kulit di } \\
\text { wilayah } \\
\text { Jajmau } \\
\text { Kanpur India }\end{array}$ & $\begin{array}{l}\text { Lama waktu }(2 \& 7 \\
\text { hari }) \text { dan konsentasi } \\
\text { air limbah }(25 \mathrm{ml}, 50 \\
\mathrm{ml}, 75 \mathrm{ml}, 100 \mathrm{ml})\end{array}$ & $\begin{array}{lr}\text { Kemampuan } & \\
\text { tanaman } & \text { dalam } \\
\text { menghadapi } & \text { stress } \\
\text { oksidatif } & \text { pada } \\
\text { pengolahan limbah } \\
\text { penyamakan kulit }\end{array}$ & ANOVA \\
\hline $\begin{array}{l}\text { (Zewge, Woldemichael, \& Leta, } \\
\text { 2011) Potential of Water } \\
\text { Hyacinth (Eichhornia crassipes } \\
\text { (Mart.) Solms) for The Removal } \\
\text { of Chromium From Tannery } \\
\text { Eflluent in Constructed Pond } \\
\text { System }\end{array}$ & $\begin{array}{l}\text { SINET : Ethiopian Journal of Science } \\
\text { https://www.ajol.info/index.php/sinet/a } \\
\text { rticle/view/78234 }\end{array}$ & $\begin{array}{l}\text { Air limbah } \\
\text { buatan }\end{array}$ & $\begin{array}{l}\text { Konsentrasi limbah } \\
(0,3,5,7,10,20 \\
\mathrm{mg} / \mathrm{l})\end{array}$ & $\begin{array}{l}\text { Kemampuan eceng } \\
\text { gondok dalam } \\
\text { menurunkan } \mathrm{Cr}\end{array}$ & $\begin{array}{l}\text { Tidak } \\
\text { dijelaskan }\end{array}$ \\
\hline $\begin{array}{l}\text { (T \& Vijayalakshmi, 2019) } \\
\text { Physicochemical } \\
\text { Characterization of Tannery } \\
\text { Effluent and Its Treatment Using } \\
\text { Eichhornia crassipes }- \text { A } \\
\text { Phytoremediation Study }\end{array}$ & $\begin{array}{l}\text { International Journal of Engineering } \\
\text { Development and Research } \\
\text { https://www.ijedr.org/viewfull.php?\&p } \\
\text { _id=IJEDR1904069 }\end{array}$ & $\begin{array}{l}\text { Air limbah } \\
\text { industri } \\
\text { penyamakan } \\
\text { di Nagelkeni, } \\
\text { Chennai, } \\
\text { Tamilnadu }\end{array}$ & $\begin{array}{l}\text { Konsentrasi limbah } \\
(0.6 ; 0.8 ; 1 \mathrm{~m} / \mathrm{l})\end{array}$ & $\begin{array}{l}\text { Kemampuan } \\
\text { menurunkan } \\
\text { parameter fisik-kimia } \\
\text { air limbah }\end{array}$ & $\begin{array}{l}\text { Tidak } \\
\text { dijelaskan }\end{array}$ \\
\hline
\end{tabular}

Berdasarkan Tabel 1 dapat diketahui bahwa variabel terikat yaitu penurunan kandungan logam krom dan variabel bebas pada beberapa jurnal menyebutkan lama waktu kontak (Kiran Gupta, 2014); (Putri et al., 2014); (Carreño Sayago \& Granada Torres, 2017); (Agarwal et al., 2013); (Chakrabarty et al., 2017), jumlah tanaman (Hartanti et al., 2014) dan konsentrasi limbah (Zewge et al., 2011); (T \& Vijayalakshmi, 2019). Tujuan dari semua jurnal yaitu mengetahui kemampuan fitoremediasi menggunakan tanaman eceng gondok dalam menurunkan logam komium dalam air limbah industri penyamakan kulit. 
Tabel 2

Hasil Analisis Penurunan Krom (Cr) Pada Sampel Air Limbah

\begin{tabular}{|c|c|c|c|c|c|}
\hline Peneliti, Tahun & $\begin{array}{c}\text { Sebelum } \\
\text { Perlakuan } \\
\text { (Pre) }\end{array}$ & $\begin{array}{l}\text { Setelah } \\
\text { Perlakuan } \\
\text { (Post) }\end{array}$ & Selisih & $\%$ Penurunan $\mathrm{Cr}$ & Hasil \\
\hline $\begin{array}{l}\text { (Hartanti et al., } \\
\text { 2014) }\end{array}$ & $2.71 \mathrm{mg} / \mathrm{l}$ & $\begin{array}{l}\text { Kandungan Cr dalam air limbah } \\
\text { pada hari-28 : } \\
\text { - } 2 \text { tanaman }=0.57 \mathrm{mg} / \mathrm{l} \\
\text { - } 4 \text { tanaman }=0.51 \mathrm{mg} / \mathrm{l} \\
\text { - } 6 \text { tanaman }=0.48 \mathrm{mg} / \mathrm{l}\end{array}$ & $\begin{array}{l}\text { Penyerapan Cr pada } \\
\text { hari-28 } \\
\text { - } 2 \text { tanaman }=2.14 \\
\mathrm{mg} / \mathrm{l} \\
\text { - } 4 \text { tanaman }=2.20 \\
\mathrm{mg} / \mathrm{l} \\
\text { - } 6 \text { tanaman }=2.23 \\
\mathrm{mg} / \mathrm{l}\end{array}$ & $\begin{array}{l}\text { Persentase penurunan kadar } \\
\text { Cr terbanyak pada hari ke-28 : } \\
\text { - } 2 \text { tanaman }=78.96 \% \\
\text { - } 4 \text { tanaman }=81.18 \% \\
\text { - } 6 \text { tanaman }=82.28 \%\end{array}$ & $\begin{array}{l}\text { Efektif } \\
\text { menurunkan } \\
\text { sesuai standar } \\
\text { WHO }\end{array}$ \\
\hline $\begin{array}{l}\text { (Chakrabarty et } \\
\text { al., 2017) }\end{array}$ & $1232.4 \mathrm{mg} / \mathrm{l}$ & $\begin{array}{l}\text { Kandungan Cr dalam air limbah : } \\
\text { - } 7 \text { hari }=832.8 \mathrm{mg} / \mathrm{l} \\
-15 \text { hari }=558 \mathrm{mg} / \mathrm{l}\end{array}$ & $\begin{array}{l}\text { Penurunan } \mathrm{Cr}: \\
\text { - } 7 \text { hari }=399.6 \mathrm{mg} / \mathrm{l} \\
\text { - } 15 \text { hari }=674.4 \\
\quad \mathrm{mg} / \mathrm{l}\end{array}$ & $\begin{array}{l}\text { Persentase penurunan } \mathrm{Cr}: \\
\text { - } 7 \text { hari }=32.42 \% \\
\text { - } 15 \text { hari }=54.72 \%\end{array}$ & Kurang efektif \\
\hline $\begin{array}{l}\text { (Agarwal et al., } \\
\text { 2013) }\end{array}$ & $7.6 \mu \mathrm{g} / \mathrm{l}$ & $\begin{array}{l}\text { Kandunan Cr dalam air limbah : } \\
\text { - } 10 \text { hari }=0.08 \mu \mathrm{g} / 1 \\
\text { - } 20 \text { hari }=0.04 \mu \mathrm{g} / 1\end{array}$ & $\begin{array}{l}\text { Penurunan } \mathrm{Cr}: \\
\text { - } 10 \text { hari }=7.52 \mu \mathrm{g} / \mathrm{l} \\
\text { - } 20 \text { hari }=7.56 \mu \mathrm{g} / \mathrm{l}\end{array}$ & $\begin{array}{l}\text { Penurunan } \mathrm{Cr}: \\
\text { - } 10 \text { hari }=98.94 \% \\
\text { - } 20 \text { hari }=99.47 \%\end{array}$ & $\begin{array}{l}\text { Efektif } \\
\text { menurunkan } \\
\text { sesuai standar } \\
\text { WHO }\end{array}$ \\
\hline $\begin{array}{l}\text { (T \& } \\
\text { Vijayalakshmi, } \\
\text { 2019) }\end{array}$ & $15.96 \mathrm{mg} / \mathrm{l}$ & $\begin{array}{l}\text { Kandungan Cr dalam air limbah } \\
\begin{array}{l}\text { - Konsentrasi } \quad 0.6 \mathrm{mg} / \mathrm{l}=2.32 \\
\mathrm{mg} / \mathrm{l}\end{array} \\
\text { - Konsentrasi } 0.8 \mathrm{mg} / \mathrm{l}=1.42 \\
\mathrm{mg} / \mathrm{l} \\
\text { - } \mathrm{Konsentrasi} \quad 1.0 \mathrm{mg} / \mathrm{l}=0.84 \\
\mathrm{mg} / \mathrm{l}\end{array}$ & 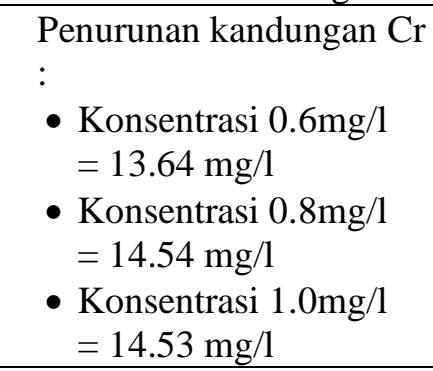 & $\begin{array}{l}\text { Persentase penurunan } \\
\text { kandungan Cr: } \\
\text { - Konsentrasi } 0.6 \mathrm{mg} / \mathrm{l}= \\
85.46 \% \\
\text { - Konsentrasi } 0.8 \mathrm{mg} / \mathrm{l}= \\
91.10 \% \\
\text { - Konsentrasi } 1.0 \mathrm{mg} / \mathrm{l}= \\
91.09 \% \\
\end{array}$ & Kurang efektif \\
\hline
\end{tabular}


Berdasarkan Tabel 2, dapat diketahui bahwa dua jurnal menyatakan fitoremedasi menggunakan eceng gondok efektif dalam menurunkan kadar krom hingga sesuai standar WHO (Hartanti et al., 2014); (Agarwal et al., 2013) dan tiga jurnal menyatakan fitoremediasi berhasil menurunkan kandungan krom (Cr) dalam sampel air limbah industri penyamakan kulit namun hasil penurunan kurang efektif kaena belum sesuai dengan standar WHO (Chakrabarty et al., 2017); (Carreño Sayago \& Granada Torres, 2017); (T \& Vijayalakshmi, 2019).

\section{Tabel 3}

Hasil Analisis Penurunan Krom (Cr) Pada Tumbuhan Eichhornia crassipes

\begin{tabular}{|c|c|c|c|c|c|}
\hline $\begin{array}{l}\text { Peneliti, } \\
\text { Tahun }\end{array}$ & Sampel Air Limbah & $\begin{array}{l}\text { Sebelum } \\
\text { Perlakuan (Pre) }\end{array}$ & $\begin{array}{l}\text { Setelah } \\
\text { Perlakuan (Post) }\end{array}$ & Penurunan $\mathrm{Cr}$ & Hasil \\
\hline $\begin{array}{l}\text { (Putri et al., } \\
\text { 2014) }\end{array}$ & $\begin{array}{l}\text { Air limbah industri } \\
\text { penyamakan kulit di } \\
\text { Desa Sukaregang, } \\
\text { Garut }\end{array}$ & $\begin{array}{l}\text { Kandungan } \mathrm{Cr} \\
\text { pada: } \\
\text { Batang+daun: } \\
3.08 \mu \mathrm{g} / \mathrm{g} \\
\text { Akar: } 1.88 \mu \mathrm{g} / \mathrm{g}\end{array}$ & $\begin{array}{l}\text { Nilai rata-rata hari } \\
\text { ke-7 } \\
\text { Batang + daun: } \\
0.387 \mu \mathrm{g} / \mathrm{g} \\
\text { Akar: } 1.090 \mu \mathrm{g} / \mathrm{g} \\
\text { Nilai rata-rata hari } \\
\text { ke-14 } \\
\text { Batang + daun: } \\
0.025 \mu \mathrm{g} / \mathrm{g} \\
\text { Akar: } 0.285 \mu \mathrm{g} / \mathrm{g} \\
\text { Nilai rata-rata hari } \\
\text { ke-21 } \\
\text { Batang + daun: } \\
0.186 \mu \mathrm{g} / \mathrm{g} \\
\text { Akar: } 0.448 \mu \mathrm{g} / \mathrm{g} \\
\end{array}$ & $\begin{array}{l}\text { E. crassipes memiliki kemampuan } \\
\text { tertinggi dalam penyerapan logam } \mathrm{Cr} \\
\text { limbah penyamakan kulit dengan rata- } \\
\text { rata penyerapannya sebesar } 1,5395 \mathrm{~g} / \mathrm{g}\end{array}$ & $\begin{array}{l}\text { Berhasil } \\
\text { menurunkan }\end{array}$ \\
\hline $\begin{array}{l}\text { (Zewge et } \\
\text { al., 2011) }\end{array}$ & Air limbah buatan & $\begin{array}{l}\text { Daun }=5 \mathrm{mg} / 1 \\
\text { Akar }=15 \mathrm{mg} / 1\end{array}$ & $\begin{array}{l}\text { Penyerapan } \mathrm{Cr} \\
\text { tertinggi menurut } \\
\text { hari ke- } 42\end{array}$ & $\begin{array}{l}\text { Penyerapan } \mathrm{Cr} \text { tertinggi pada hari ke- } 42 \\
\text { pada konsentrasi } 20 \mathrm{mg} / \mathrm{l}\end{array}$ & $\begin{array}{l}\text { Berhasil } \\
\text { menurunkan }\end{array}$ \\
\hline
\end{tabular}




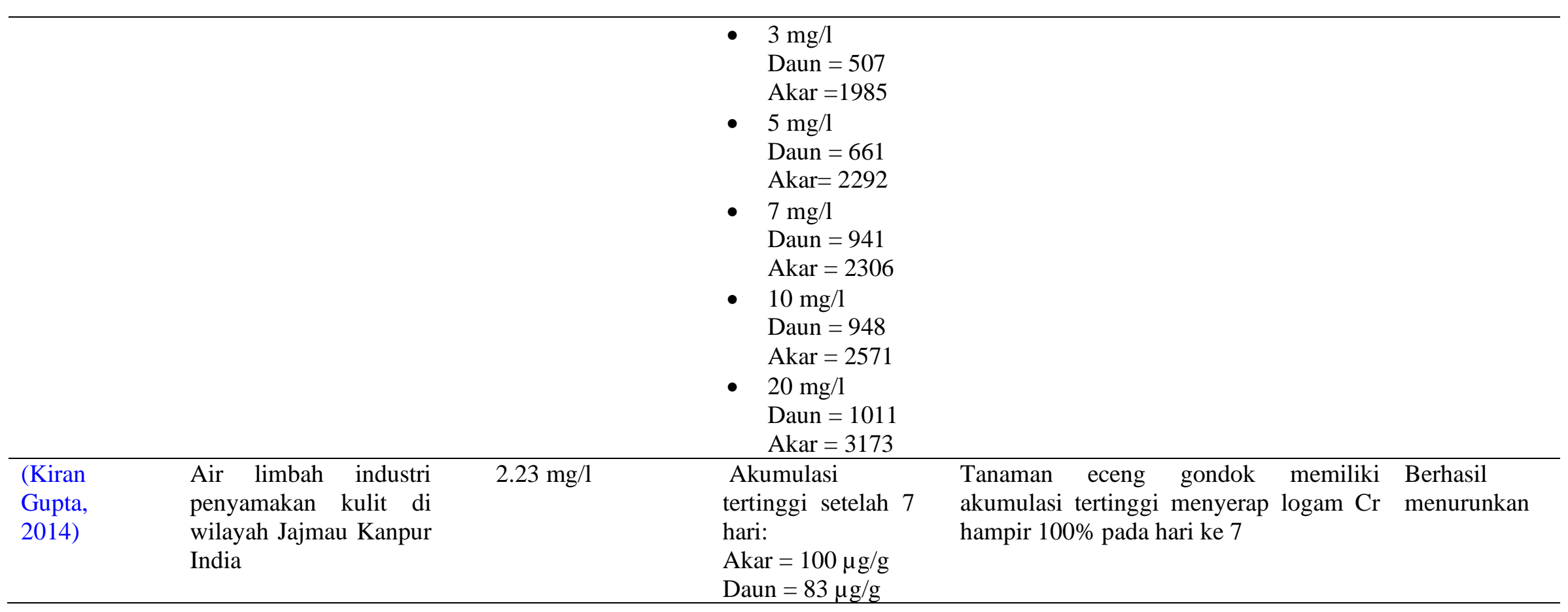

Berdasarkan Tabel 3, dapat diketahui semua jurnal menunjukkan bahwa fitoremediasi dinyatakan berhasil menurunkan kandungan krom (Cr) pada sampel air limbah karena adanya akumulasi logam berat krom (Cr) pada bagian tumbuhan eceng gondok meliputi bagian akar (Putri et al., 2014); (Zewge et al., 2011); (Kiran Gupta, 2014),, batang + daun (Putri et al., 2014), dan daun (Zewge et al., 2011); (Kiran Gupta, 2014). 


\section{B. Pembahasan}

Berdasarkan hasil delapan jurnal diatas, diketahui satu jurnal menggunakan sampel air limbah buatan dan tujuh jurnal lainnya menggunakan sampel air limbah industri penyamakan kulit. Metode penelitian yang dipakai pada keseluruhan jurnal yaitu metode ekperimental. Metode eksperimental ini merupakan penelitian yang bertujuan untuk mengetahui pengaruh dari variabel bebas dengan variabel terikat. Variabel bebas yang diperoleh pada jurnal tersebut meliputi lama waktu kontak, konsentrasi air limbah dan kerapatan tanaman eceng gondok. Tumbuhan $E$. crassipes ini memiliki kemampuan untuk menyerap logam berat seperti $\mathrm{Cd}, \mathrm{Hg}, \mathrm{Pb}$ dan $\mathrm{Cr}$ dengan rata-rata penyerapan logam berat terbanyak berada di akar (Irhamni; et al., 2018).

Limbah aktivitas produksi industri penyamakan kulit memiliki karakteristik yaitu terkadang berbusa, kandungan sulfida yang cukup tinggi, $\mathrm{pH}$ berkisar $3-12$, kandungan bahan organik yang tinggi, berbau busuk, dan kandungan warna yang cukup pekat (Setiyono, 2014). Pada limbah penyamakan kulit ini mengandung polutan logam berat berbahaya seperti kromium (Cr) yang dapat menurunkan kualitas sumber air di sekitarnya (Ugya \& Aziz, 2016). Menurut WHO (2019) menyatakan standar baku mutu kandungan total kromium $(\mathrm{Cr})$ dan kromium heksavalen (Cr VI) dalam air limbah industri penyamakan kulit berurut sebesar 0.5 $\mathrm{mg} / \mathrm{l}$ dan $0.05 \mathrm{mg} / \mathrm{l}$. Kandungan krom dalam air limbah yang melebihi batas baku mutu dapat menyebabkan gangguan keseimbangan lingkungan. Pengolahan air limbah pada industri penyamakan kult ini perlu dilakukan secara efektif dan efisien sehingga memenuhi persyaratan parameter air limbah salah satunya melalui metode fitoremediasi memanfatkan tanaman eceng gondok untuk menurunkan kandungan logam krom (Cr) dalam limbah penyamakan kulit.

Berdasarkan 8 jurnal tersebut diketahui metode persiapan tanaman dilakukan dengan sistem batch. Sistem batch ini merupakan teknik menanam tanaman pada media air limbah dan proses pengukuran sampelnya dilakukan di akhir perlakuan (Wahyudi \& Hendraningsih, 2020). Pada penelitian yang dilakukan oleh (Chakrabarty et al., 2017) menyebutkan metode ini dilakukan dengan cara memasukan limbah cair ke dalam bak percobaan lalu ditanami tumbuhan eceng gondok yang telah teraklimatisasi. Pada penelitian (Hartanti et al., 2014) menyebutkan jumlah tumbuhan eceng gondok yang digunakan dalam penelitiannya yaitu 2 tanaman (K1), 4 tanaman (K2) dan 6 tanaman (K3). Penelitian (Agarwal et al., 2013) menyebutkan setelah tanaman dicuci dengan air suling kemudian diletakkan pada wadah plastik diameter $60 \mathrm{~cm}$ dan tinggi $40 \mathrm{~cm}$ yang mengandung $20 \mathrm{~L}$ air limbah penyamakan. Tiap wadah tersebut diisi $300 \mathrm{gr}$ tanaman eceng gondok. Tanaman tersebut ditumbuhkan dalam durasi 10 hari dan 20 hari untuk dilakukan pengukuran kandungan $\mathrm{Cr}$.

Berdasarkan jurnal tersebut diketahui proses pengujian kandungan logam berat krom (Cr) menggunakan metode Atomic Absorption Spectrophotometry (AAS) dengan teknik destruksi kering dan destruksi basah. Destruksi kering merupakan 
perombakan logam organik di dalam sampel menjadi logam-logam anorganik dengan jalan pengabuan sampel dalam muffle furnace dan memerlukan suhu pemanasan tertentu tergantung pada jenis sampel yang akan dianalisis (Kristianingrum, 2012). Penelitian (T \& Vijayalakshmi, 2019) menyatakan setelah proses aklimasi tanaman lalu eceng gondok dicuci bersih dengan air suling untuk menghilangkan partikel tanah. Tahap selanjutnya sebanyak $300 \mathrm{gr}$ tanaman dipotong lalu dikeringkan di oven (Agarwal et al., 2013) namun peneliti lain menggunakan tanaman dengan berat 180 gr (Carreño Sayago \& Granada Torres, 2017) dan 200 gr (T \& Vijayalakshmi, 2019). Langkah selanjutnya tanaman dikeringkan di udara selama 2 hari dan dikeringkan dengan oven suhu $100^{\circ} \mathrm{C}$ selama 4 jam. Pada kondisi sampel masih hangat, diabukan,serta dilanjutkan digesti asam (Chakrabarty et al., 2017).

Proses pengujian sampel kandungan logam pada beberapa jurnal menyebutkan dengan menggunakan teknik destruksi basah. Destruksi basah merupakan perombakan sampel dengan asam kuat (asam nitrat, asam sulfat, asam perklorat, asam klorida) kemudian dioksidasi dengan oksidator. Pada teknik ini biasanya digunakan alat wet digester untuk melakukan destruksi (Kristianingrum, 2012). Penelitian (Kiran Gupta, 2014) menyebutkan setelah tanaman eceng gondok dicuci kemudian dipotong dan dikeringkan menggunakan oven pada suhu $80^{\circ} \mathrm{C}$, namun penelitian lain menyebutkan sampel dikeringkan di oven pada suhu $60^{\circ} \mathrm{C}$ lalu ditimbang \pm 0.2 gram lalu ditambahkan larutan asam nitrat pekat, asam peroksida (Putri et al., 2014) atau larutan $\mathrm{KMnO}_{4}$ (Hartanti et al., 2014). Tahap selanjutnya tanaman kemudian dibuat serbuk dengan metode Kjendhal pada suhu $150^{\circ} \mathrm{C}$ selama 3 jam kemudian didinginkan di suhu ruangan selama 15 menit. Setelah dingin larutan disaring menggunakan kertas saring Whatman (ukuran $0.45 \mu \mathrm{m}$ ) dimasukan ke dalam labu ukur $50 \mathrm{ml}$, didilusi, dan deionisasi air (Zewge et al., 2011).

Penurunan kandungan krom (Cr) pada limbah industri penyamakan kulit menggunakan tanaman $E$. crassipes dapat dilihat tingkat efektivitasnya melalui hasil kandungan krom sesudah (post) perlakuan fitoremediasi dibandingkan standar baku WHO. Hasil penurunan kandungan krom (Cr) dinyatakan kurang efektif jika hanya terjadi penurunan kandungan krom $(\mathrm{Cr})$ namun belum memenuhi standar baku mutu. Hasil penelitian (Hartanti et al., 2014) menyebutkan penurunan kadar krom tertinggi pada lama waktu 28 hari pada 2 tanaman, 4 tanaman dan 6 tanaman berurutan sebesar 78.96\% ; 81.18\% ; 82.28\%. (T \& Vijayalakshmi, 2019) dalam penelitiannya menyebutkan penurunan kadar krom berdasarkan konsentrasi sampel air $0.6 \mathrm{mg} / \mathrm{l}, 0.8 \mathrm{mg} / \mathrm{l}, 1 \mathrm{mg} / \mathrm{l}$ berurutan sebesar $85.46 \%$; 91.10\% ; 94.73\%. Artikel penelitian dari (Agarwal et al., 2013) menyebutkan penurunan kandungan krom $(\mathrm{Cr})$ dalam air limbah penyamakan sebesar $98.94 \%$ dalam 10 hari dan $99.47 \%$ dalam 20 hari. (Carreño Sayago \& Granada Torres, 2017) dalam hasil penelitiannya menyebutkan penurunan kromium heksavalen (Cr VI) tertinggi sebesar $72 \%$ dalam waktu 25 hari. Penelitian yang dilakukan oleh (Chakrabarty et al., 2017) menyatakan efisiensi penurunan krom setelah 7 hari sebesar $32.42 \%$ dan 15 hari 
sebesar $54.72 \%$. Berdasarkan hasil analisis tersebut fitoremediasi dinyatakan efektif jika hasil setelah perlakuan (post) memenuhi baku mutu kandungan kromium air limbah yang ditetapkan oleh WHO, sehingga hasil penelitian dari jurnal yang dikatakan efektif yaitu jurnal penelitian (Hartanti et al., 2014) dan (Agarwal et al., 2013).

Berdasarkan jurnal-jurnal tersebut diketahui bahwa penurunan kadar kromium (Cr) dalam sampel air limbah menggunakan tanaman eceng gondok dikatakan efektif pada lama waktu 10 hari, 20 hari dan 28 hari. Efisiensi penurunan pada waktu 10 hari sebesar $98.94 \%$, 20 hari sebesar $99.47 \%$ dan 28 hari sebesar $82.28 \%$. Hal ini sejalan dengan penelitian (Sumardi et al., 2019) menyebutkan waktu kontak yang lebih lama mempengaruhi tingginya kadar $\mathrm{Cr}$ yang berhasil diserap oleh tumbuhan eceng gondok. Akan tetapi, keadaan ini dipengaruhi juga oleh konsentrasi sampel air limbah yang digunakan. Pada penelitiannya tersebut menyatakan bahwa tumbuhan eceng gondok pada minggu kedua untuk konsentrasi kadar kromium sebesar $10 \mathrm{ppm}, 20 \mathrm{ppm}$ dan $30 \mathrm{ppm}$ telah mengalami perubahan pada daun dan batang yakni adanya kerusakan dalam pertumbuhan tanaman tersebut. Penelitian oleh (T \& Vijayalakshmi, 2019) menyebutkan konsentrasi kromium maksimal untuk tanaman eceng gondok tumbuh yaitu $1,0 \mathrm{mg} / \mathrm{l}$.

Penelitian yang dilakukan oleh (Gupta, 2014) menyebutkan kandungan krom pada sampel air tersebut sebesar $2.43 \mathrm{mg} / \mathrm{l}$ kemudian setelah perlakuan diperoleh hasil kandungan krom pada tumbuhan di bagian akar diketahui sebesar $2.2 \mu \mathrm{g} / \mathrm{g}$ dan bagian daun sebesar $0.83 \mu \mathrm{g} / \mathrm{g}$. Hasil tersebut menunjukkan efisiensi penyerapan krom pada bagian tumbuhan eceng gondok dinyatakan efektif menurunkan kadar krom (Cr) hingga 100\% dalam 7 hari sehingga berhasil menghilangkan kandungan logam berat krom dalam sampel air limbah. Penelitian lain dilakukan oleh (Putri et al., 2014) menyebutkan kandungan krom dalam tumbuhan E. crassipes di bagian akar dan batang+daun selama 7 hari sebesar $57.97 \%$ dan $12.56 \%$; hari ke-14 sebesar 9.25\% dan 0.81\%; hari ke-21 sebesar 23.82\% dan 6.03\%. Penelitian (Zewge et al., 2011) menyebutkan rata-rata penyerapan $\mathrm{Cr}$ terbanyak selama waktu kontak 42 hari pada konsentrasi $3 \mathrm{mg} / \mathrm{l} ; 5 \mathrm{mg} / \mathrm{l} ; 7 \mathrm{mg} / \mathrm{l} ; 10 \mathrm{mg} / \mathrm{l} ; 20 \mathrm{mg} / \mathrm{l}$ berurut $91 \%$, 85\%, $80 \%, 80 \%, 69 \%$. Berdasarkan hasil penelitian tersebut menunjukkan bahwa fitoremediasi dapat menurunkan kandungan $\mathrm{Cr}$ melalui kemampuan E. crassipes dalam menyerap kandungan $\mathrm{Cr}$ pada sampel air.

Berdasarkan hasil analisis semua jurnal terdapat beberapa variabel seperti lama waktu, jumlah tanaman, dan konsentrasi air limbah mempengaruhi hasil penurunan kandungan krom (Cr). Hasil penelitian (Sumardi et al., 2019) menyebutkan lama waktu kontak mempengaruhi efisiensi tanaman E. crassipes dalam menurunkan kandungan krom pada air limbah. Pada hasil ekperimen tersebut tanaman $E$. crassipes memiliki daya serap tertinggi pada konsentrasi limbah 50 ppm selama 4 minggu. Penelitian yang dilakukan oleh (Jahan et al., 2014) mengalokasikan jumlah tanaman sebanyak 3 individu pada masing-masing jenis tanaman air E. crassipes, Pistia stratiotes dan Spirodella plyrrhiza. Hasil penelitian tersebut menyatakan 
tanaman E. crassipes dapat menurunkan hingga 92.76\% kandungan logam berat $\mathrm{Cr}$ pada sampel.

Industri penyamakan kulit menghasilkan limbah padat dan cair yang berasal dari sisa proses produksi penyamakan kulit. Hasil studi kasus yang dilakukan oleh (Wulandari \& Nasution, 2018) pada masyarakat yang tinggal sekitar industri penyamakan kulit di Desa Ringingagung Kecamatan Magetan menyebutkan pencemaran yang terjadi di Sungai Gandong akibat limbah industri penyamakan menimbulkan bau busuk bahkan hingga mempengaruhi kualitas air sumur di sekitarnya. Akumulasi kromium dalam tubuh dapat menyebabkan gangguan kesehatan seperti peningkatan sensitivitas kulit dan kerusakan ginjal (Muthoharoh, 2018). Hasil penelitian (Khan et al., 2013) menyebutkan sebanyak 240 peserta termasuk 120 pekerja laki-laki daro industri penyamakan kulit di Sialkot Pakistan diketahui sebanyak 15 orang mengalami ruam kulit, 14 orang mengalami bronkrritis kronis, 10 orang mengalami gastritis dan 4 orang mengalami konjungtivitis. Pada penelitian tersebut juga menyatakan sebanyak $54 \%$ pekerja penyamakan kulit memiliki kadar $\mathrm{Cr}$ dalam darah yang melebihi batas maksimal akibat paparan kromium yang berlebihan. Keadaan ini menyebabkan penurunan produktivitas akibat ketidakseimbangan fungsi tubuh karena paparan krom yang berlebih.

Berdasarkan hasil analisis delapan jurnal menunjukkan terdapat penurunan kadar kromium dalam air limbah akibat akumulasi krom pada tanaman eceng gondok. Hasil tersebut menunjukkan lama waktu yang dapat menurunkan kandungan kromium dalam air sampel yaitu 7 hari, 14, hari, 21 hari, 10 hari, 20 hari, 25 hari, 15 hari, 42 hari. Fitoremediasi dikatakan efektif jika berhasil menurunkan kadar Cr sesuai dengan standar WHO yaitu $0.5 \mathrm{mg} / \mathrm{l}$. Berdasarkan hal tersebut, diketahui hasil penurunan krom dinyatakan efektif menurunkan kandungan $\mathrm{Cr}$ hingga sesuai standar baku mutu yaitu pada lama waktu kontak 10 hari, 20 hari dan 28 hari. Metode fitoremediasi memiliki beragam kemudahan karena memanfaatkan tumbuhan air yang mudah diberdayakan. Oleh karena itu, pemanfaatan metode fitoremediasi ini diperlukan pengawasan terhadap pertumbuhan tanaman eceng gondok agar dapat bekerja optimal menurunkan kandungan logam krom dalam air limbah.

\section{Kesimpulan}

Hasil kajian literatur diperoleh bahwa jumlah tanaman, lama waktu kontak dan konsentrasi limbah mempengaruhi penurunan krom pada air limbah penyamakan. Berdasarkan hasil analisis jurnal diperoleh bahwa fitoremediasi dapat menurunkan kadar kromium dalam air limbah akibat akumulasi krom pada tanaman eceng gondok. Hasil tersebut menunjukkan lama waktu efektif yang dapat menurunkan kandungan kromium dalam air sampel sesuai standar WHO yaitu 10 hari, 20 hari, 28 hari. Berdasarkan kelebihan dan kekurangan jurnal dalam kajian literatur ini, maka sebaiknya bagi peneliti selanjutnya mencantumkan informasi penelitian secara lengkap seperti 
Dwi Astuti, Nurul Sukmawati, Rezania Asyfiradayati, Sri Darnoto

langkah pengujian sampel, langkah pengambilan sampel, nilai sebelum dan sesudah perlakuan serta pembahasan efisiensi penurunan logam kromium. 


\section{BIBLIOGRAFI}

Adhani, Rosihan; Husaini. (2017). Logam Berat Sekitar Manusia (II; Syarifah Kholishotunnisa, Ed.). Banjarmasin: Lambung Mangkurat University Press. Google Scholar

Agarwal, Anamika, Singh, H. P., \& Rai, J. P. N. (2013). Bioremediation of tannery effluent by using Pseudomonas fluorescens and Eichhornia crassipes and its effect on Wheat seed germination and plant growth. G-Journal of Environmental Science and Technology, 1(1), 20-23. Google Scholar

Carreño Sayago, Uriel Fernando, \& Granada Torres, Carlos Arturo. (2017). Design, Development, and Evaluation of a Laboratory-Scale Phytoremediation System Using Eichhornia Crassipes for the Treatment of Chromium-Contaminated Waters. Tecciencia, 12(22), 7-14. Google Scholar

Chakrabarty, Trina, Afrin, Rezuana, Mia, Md Younus, \& Hossen, Md Zakir. (2017). Phytoremediation of Chromium and some chemical parameters from Tannery effluent by using water Hyacinth (Eichhornia craassipes). Research in Agriculture Livestock and Fisheries, 4(3), 151-156. Google Scholar

Chakraborty, Debesh, \& Mukhopadhyay, Kakali. (2012). Water pollution in India: an Input-Output Analysis Draft. 20th IIOA Conference Bratislava, June 25-29, 1-30. Google Scholar

Direktorat Pengawasan Produk dan Bahan Berbahaya, Badan POM RI. (2010). Mengenal Logam Beracun. Badan Pengawas Obat Dan Makanan (BPOM) RI, 24.

Gupta, Bhaskar, \& Huang, Bingru. (2014). Mechanism of salinity tolerance in plants: physiological, biochemical, and molecular characterization. International Journal of Genomics, 2014. Google Scholar

Gupta, Kiran. (2014). Modulation of antioxidant defence system for detoxification of oxidative stress caused by tannery effluent in Eichhornia crassipes. International Journal of Environment, 3(1), 101-110. Google Scholar

Hartanti, Putri Indah, Haji, Alexander T. S., \& Wirosoedarmo, Ruslan. (2013). Pengaruh Kerapatan Tanaman Eceng Gondok (Eichornia Crassipes) Terhadap Penurunan Logam Chromium Pada Limbah Cair Penyamakan Kulit The Influence Of Plant Density Water Hyacinth (Eichornia Crassipes) Againts Metal Loss Chromium In Tannery Waste Liquid. Jurnal Sumberdaya Alam Dan Lingkungan, 31-37. Google Scholar

Hartanti, Putri Indah, Haji, Alexander Tunggul Sutan, \& Wirosoedarmo, Ruslan. (2014). Pengaruh kerapatan tanaman eceng gondok (Eichornia crassipes) terhadap penurunan logam chromium pada limbah cair penyamakan kulit. Jurnal Sumberdaya Alam Dan Lingkungan, 1(2), 31-37. Google Scholar 
Dwi Astuti, Nurul Sukmawati, Rezania Asyfiradayati, Sri Darnoto

Irhamni;, Pandia, Setiaty, Purba, Edison, \& Hasan, Wirsal. (2018). Kajian Akumulator Beberapa Tumbuhan Air dalam Menyerap Logam Berat secara Fitoremediasi. Jurnal Serambi Engeneering, 3(2), 344-351. Google Scholar

Kristianingrum, Susila. (2012). Kajian berbagai proses destruksi sampel dan efeknya. Prosiding Seminar Nasional Penelitian, Pendidikan Dan Penerapan MIPA, Fakultas MIPA, Universitas Negeri Yogyakarta, 2. Google Scholar

Muthoharoh, Rizqi. (2018). Pemanfaatan Tumbuhan Semanggi (Marsilea crenata) Sebagai Fitoremediator Logam Kromium Total (Cr) Pada Limbah Cair Batik (Vol. 1). Universitas Jember, Jember. Google Scholar

Nurlaili, Rizqi Aulia, Rahayu, Yuni Sri, \& Dewi, Sari Kusuma. (2020). Pengaruh Mikoriza Vesikular Arbuskular (MVA) dan Silika (Si) terhadap Pertumbuhan Tanaman Brassica juncea pada Tanah Tercemar Kadmium (Cd). Google Scholar

Putri, Yola Desnera, Holik, Holis Abdul, Musfiroh, Ida, \& Aryanti, Anisa D. (2014). Pemanfaatan tanaman eceng-ecengan (Ponteridaceae) sebagai agen fitoremediasi dalam pengolahan limbah krom. Indonesian Journal of Pharmaceutical Science and Technology, 1(1), 26. Google Scholar

Safarrida, Anna, \& Ngadiman, Widada J. (2015). Fitoremediasi kandungan kromium pada limbah cair menggunakan tanaman air. J Bioteknol Biosains Indones, 2, 5559. Google Scholar

Setiyono, Satmoko Yudo. (2014). Panduan Pengelolaan Instalasi Pengolahan Air Limbah Industri Otomotif. BPPT Press. Google Scholar

T, Shehnaz Begum, \& Vijayalakshmi, M. (2019). Physicochemical characterization of tannery effluent and its treatment using Eichhornia crassipes - A Phytoremediation study. 7(4), 390-395.

Ugya, Adamu Yunusa, \& Aziz, A. (2016). A Concise Review on the Effect of Tannery Waste Water on Aquatic Fauna. Merit Journal of Medicine and Medical Sciences, 4(11), 476-479. Google Scholar

Wahyudi, Ahmad, \& Hendraningsih, Listiari. (2020). BIOGAS Fermentasi Limbah Peternakan (Vol. 1). UMMPress. Google Scholar

Woldemichael, Daniel, Zewge, Feleke, \& Leta, Seyoum. (2011). Potential of water Hyacinth (Eichhornia Crassipes (Mart.) Solms) for the removal of chromium from trannery effluent in constructed pond system. Ethiop. J. Sci, 34, 49-62. Google Scholar

Zewge, F., Woldemichael, D., \& Leta, Seyoum. (2011). Potential of water hyacinth (Eichhornia crassipes (Mart.) Solms) for the removal of chromium from tannery effluent in constructed pond system. SINET: Ethiopian Journal of Science, 34(1), 
Kajian Literatur Tentang Reduksi Kromium dalam Air Limbah Penyamakan Kulit dengan Fitoremediasi

49-62. Google Scholar

\section{Copyright holder:}

Dwi Astuti, Nurul Sukmawati, Rezania Asyfiradayati, Sri Darnoto (2022)

First publication right:

Syntax Literate: Jurnal Ilmiah Indonesia

This article is licensed under:
(c) (i) (2) 